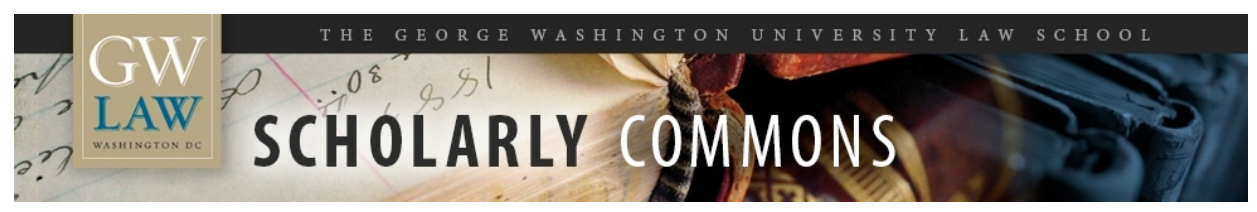

\title{
The Scope of the Removal Power Is Ripe for Reconsideration
}

Richard J. Pierce Jr

George Washington University Law School, rpierce@law.gwu.edu

Follow this and additional works at: https://scholarship.law.gwu.edu/faculty_publications

Part of the Law Commons

\section{Recommended Citation}

Pierce, Richard J., The Scope of the Removal Power Is Ripe for Reconsideration (2019). GWU Law School Public Law Research Paper No. 2019-9; GWU Legal Studies Research Paper No. 2019-9. Available at SSRN: https://papers.ssrn.com/abstract=3360375

This Article is brought to you for free and open access by the Faculty Scholarship at Scholarly Commons. It has been accepted for inclusion in GW Law Faculty Publications \& Other Works by an authorized administrator of Scholarly Commons. For more information, please contact spagel@law.gwu.edu. 


\section{The Scope of the Removal Power Is Ripe for Reconsideration}

By Richard J. Pierce Jr.

I have been teaching and writing about the power of the president to remove officers of the United States for over 40 years. Until recently, however, I have been content to describe the Supreme Court's opinions that address the scope issue without attempting to persuade the Court to change its approach to the issue.

The issue has become particularly important in the last few years for two reasons. First, the scope issue has become particularly important because of the increasing controversy that surrounds the scope of the removal power in the context of officers who perform purely adjudicatory functions. In its 2018 opinion in Lucia v. SEC, the Supreme Court held that SEC ALJs are officers of the United States. ${ }^{1}$ The holding is broad enough to encompass virtually all ALJs and AJs. ${ }^{2}$ In a brief filed in the Supreme Court in that case, the solicitor general (SG) tried to persuade the Court to hold that the longstanding limits on the power to remove an ALJ are either invalid or meaningless. ${ }^{3}$ Those limits are based on due process. The Court decided not to address the removal issue in that case, but it is only a matter of time until the Court addresses the issue.

The second reason the scope issue has become particularly important is tied to the growing movement to broaden the scope of the power of the president to remove officers who perform executive functions. $\mathrm{C}$ That effort is motivated by concern that limits on the removal power interfere impermissibly with the president's responsibility to perform the functions vested in the president by Article II of the Constitution. 
Thus, for instance, the Supreme Court expanded the scope of the removal power and reduced the power of Congress to limit the removal power in its 2010 opinion in Free Enterprise Fund v. Public Company Accounting Oversight Board. ${ }^{4}$ The Court held that Congress cannot limit the president's removal power by imposing two or more layers of for cause limits on the removal power. Because the president can only remove a member of the Securities and Exchange Commission (SEC) for cause, the Court wrote, the for cause limit on the SEC's power to remove members of the Public Company Accounting Oversight Board (PCAOB) violated Article II.

A panel of the D.C. Circuit took a step beyond Free Enterprise Fund in 2016, holding that the single layer of for cause limit on the president's power to remove the director of the Consumer Financial Protection Board (CFPB) violated Article II. ${ }^{5}$ The en banc D.C. Circuit overturned that decision, but there are reasons to believe that final resolution of the issue is far from over. The judge who wrote the panel opinion, Judge Kavanagh, was appointed to the Supreme Court, where he will be in a better position to influence the outcome of the inevitable future disputes about the scope of the removal power. In 2018, a panel of the Fifth Circuit renewed the dispute in an analogous context by holding unconstitutional the for cause limit on the president's power to remove the director of the Federal Housing Finance Agency (FHFA). ${ }^{6}$

This article looks at the history of Supreme Court cases addressing removal power. Based on a discussion of those cases, including a landmark opinion written by former chief justice (and former president) William Howard Taft, the article concludes that the Supreme Court should hold that the president must have the power to remove at will any officer who performs executive functions to enable the president to perform the functions vested in the president by Article II. By contrast, the article concludes the Court should hold that due process precludes the president from 
having the power to remove at will an officer whose sole responsibilities are to adjudicate disputes between private parties and the government.

\section{Methodology and Findings}

I began my effort to understand the scope issue by reading and studying with care all of the major judicial decisions that have addressed the scope issue. I came away from that effort with two pleasant surprises. First, with two exceptions, the opinions are better reasoned than I remembered. Second, with the same two exceptions, the opinions form a coherent and consistent pattern. Courts consistently protect the president's power to perform the functions vested in him by Article II by holding that he or one of his immediate subordinates must have the power to remove at will any officer who performs purely executive functions. At the same time, courts consistently protect the due process rights of parties to disputes with the government by limiting the power of the president or an agency head to remove any officer who performs purely adjudicatory functions.

\section{The President Must Have the Power to Remove at Will Officers Who Perform Executive Functions}

The logical starting point in any attempt to understand the opinions that address the scope of the removal power is the 1926 opinion of Chief Justice Taft in Myers v. United States. ${ }^{7}$ That opinion upheld President Wilson's decision to remove a postmaster from office. It is often described as holding that Congress cannot limit in any way the president's power to remove any officer. That description is incomplete in ways that are misleading. Taft's 71-page opinion addressed many issues with care. 
Taft did not focus on President Wilson's removal of postmaster Myers in the 1920s. He focused primarily on President Andrew Johnson's decision to remove the Secretary of War in the 1860s. He also did not address explicitly the issue that has drawn most of the attention of courtswhether Congress can limit the president's removal power by requiring a statement of cause for removing an officer. The restriction on removal at issue in Myers was the Tenure in Office Act, a statute that Congress enacted in 1867. That statute purported to limit the president's removal power by requiring the president to obtain the permission of the Senate before removing any officer. The opinion in Myers was the logical antecedent to modern opinions like INS v. Chadha ${ }^{8}$ and Bowsher v. Synar, ${ }^{9}$ in which the Court held that Congress cannot aggrandize itself by giving itself a role in performing functions that are vested in the president by Article II.

Taft discussed in detail the controversy that led Congress to enact the Tenure in Office Act and to impeach and to attempt to remove from office President Johnson for refusing to comply with that statute by firing the Secretary of War without first obtaining the permission of the Senate. Congress and President Johnson differed dramatically with respect to the most important question at the time - how to reconstruct the country after the Civil War. Congress enacted the Tenure in Office Act in an effort to make it impossible for President Johnson to exercise the powers vested in him by Article II in the context of his attempt to reunite and reconstruct the country.

In the course of his lengthy opinion, Taft described and supported three broad propositions that are important to an understanding of the removal power. First, he explained why the president must be able to appoint many officers to be able to perform effectively the functions vested in the president by Article II. The task is far too massive to be accomplished by a president without the aid of agents. Second, he explained why the president must have the discretion to remove officers at will. If an officer attempts to move the nation in a direction that is inconsistent with the 
president's policies, the president cannot perform the functions vested in him by Article II unless he has the discretion to remove that officer. Third, if Congress wants to make it impossible for the president to perform the functions vested in him by Article II, it can do so most effectively by limiting the power of the president to remove an officer. To chief justice (and former president) Taft, it followed that Congress cannot limit the president's discretion to remove officers with executive functions.

I find Taft's explanation of his three broad propositions persuasive, particularly coming from a former president. Many of the most important later opinions repeat and build on Taft's reasoning and conclusions in Myers. Thus, for instance, the opinion in Free Enterprise Fund supports its ban on multiple levels of for cause limits on the removal power with reference to the reasoning in Myers. ${ }^{10}$ The Free Enterprise Fund opinion supplements the reasoning in Myers with reasoning based on political accountability, such as, the public cannot know who is responsible for a government policy decision unless the president has the power to remove a policy making official at will.

Similarly, Judge (now Justice) Kavanagh used reasoning like the reasoning in Myers, supplemented by reasoning based on political accountability, in his opinion that held unconstitutional the for cause limit on the president's power to remove the director of the CFPB. Thus, for instance, he emphasized that the director "unilaterally implements and enforces [nineteen] federal consumer protection statutes, covering everything from home finance to credit cards to banking practices." ${ }^{11} \mathrm{He}$ reasoned that anyone with that broad range of executive responsibilities must be removable by the president at will to allow the president to perform the functions vested in him by Article II and to allow the public to hold the president accountable for the policies the government adopts and attempts to further in each of the many contexts in which 
the director has the unilateral power to make and to implement policy on behalf of the government. The Fifth Circuit's reasoning in support of its holding that the for cause limit on the president's power to remove the director of the FHFA ${ }^{12}$ is virtually identical to the reasoning in Judge (now Justice) Kavanagh's opinion with respect to the Director of the CFPB.

Taft's opinion in Myers also includes another discussion that is important to an understanding of the Court's views with respect to the appropriate scope of the removal power. He devoted four pages of his opinion to discussion of the postmaster's argument that he could not be removed at will because the Court had upheld limits on the power of the president to remove territorial judges. ${ }^{13}$ After discussing the conflicting opinions in which the Court had addressed that question, the chief justice referred with apparent approval to the opinion of Justice McLean:

He pointed out that the argument upon which the decision rested was based on the necessity for presidential removals in the discharge by the President of his executive duties and his taking care that the laws be faithfully executed, and that such an argument could not apply to the judges, over whose judicial duties he could not properly exercise any supervision or control after their appointment and confirmation. ${ }^{14}$

The chief justice then explicitly disavowed any intent to apply the reasoning and holding in Myers to non-Article III judges:The question whether $* * *$ Congress may provide for [a territorial judge's] removal in some other way present considerations different from those that apply in the removal of executive officers, and therefore we do not decide them 15 
The opinion in Free Enterprise Fund includes a similar explicit disavowal of any intent to apply its reasoning or holding to officers who perform adjudicative functions, noting that "administrative law judges perform adjudicative functions rather than enforcement functions."16

\section{Due Process Limits the Power to Remove Officers Who Perform Only Adjudicative}

\section{Functions}

A few years after it issued its opinion in Myers, the Court issued its famous opinion in Humphrey's Executor v. United States. ${ }^{17}$ The Court upheld the statutory for cause limit on the president's power to remove an FTC Commissioner. The opinion in Humphrey's has traditionally been interpreted to be inconsistent with the opinion in Myers and to authorize Congress to create agencies with vast power that are "independent" of the president. Neither of those interpretations is supported by the reasoning in the Humphrey's opinion and the context in which the opinion was issued. The opinion in Humphrey's can support an interpretation that reconciles it with the opinion in Myers and that does not legitimate the concept of multifunction agencies that are independent of the president.

The FTC of 1935 was nothing like the modern FTC or the agencies that have been the subject of the recent decisions that have held invalid restrictions on the removal of officersPCAOB, CFPB, and FHFA. Each of those agencies has the power to make policy decisions on behalf of the government by issuing legislative rules that have the same legally binding effect as a statute. By contrast, the FTC of 1935 had no power to make policy through the issuance of rules or through any other means.

The Court distinguished the functions performed by the FTC from the executive functions performed by the officers who were the subject of the holding in Myers. The Court characterized

the FTC of 1935 as a "quasi legislative and quasi-judicial" body. ${ }^{18}$ In its capacity as a quasi- 
legislative body, the FTC of 1935 performed the functions that are performed by congressional staff and the Congressional Research Service (CRS) today. Congress had little staff support until 1946, and CRS was not created until $1970 .{ }^{19}$ In 1935 , Congress had to rely on the FTC to study the performance of markets and to make recommendations with respect to the need to enact legislation to authorize regulation of markets. FTC reports to Congress were the basis for many statutes, including the Natural Gas Act and the Federal Power Act. ${ }^{20}$ It made sense for Congress to insulate the officers in charge of conducting research for Congress from at will removal by the president.

In its capacity as a quasi-judicial body, the FTC acted as a specialized forum to adjudicate trade disputes. The Court analogized it to the Court of Claims. ${ }^{21}$ In its adjudicative capacity, the FTC of 1935 was also analogous to the Territorial Courts that the Myers Court distinguished from agencies that perform executive functions. As the Myers Court recognized, the president "could not properly exercise any supervision or control" over judges who were appointed to the Territorial courts. ${ }^{22}$ It follows that a for cause limit on the power of the president to remove a Commissioner of the FTC of 1935 was entirely consistent with the holding in Myers that the president must have the power to remove at will officers who perform executive functions.

The Court followed its opinion in Humphrey's Executor with its 1958 opinion in Wiener v. United States. ${ }^{23}$ The Court held that the president could not remove a member of the threemember War Claims Tribunal without stating a cause for removal. Wiener can be interpreted to support the proposition that due process limits the power of the president to remove an officer with adjudicative responsibilities. There was no statutory limit on the president's power to remove a member of the War Claims Tribunal. The Court adopted a construction of the statute that included such a limit because the Tribunal was tasked only with "adjudicating [claims] according to law, 
that is on the merits of each claim, supported by evidence and governing legal considerations." 24 The Court reasoned that Congress intended the members of the Tribunal to have the same freedom from potential outside influences that the judges of the District Courts and the Court of Claims had. ${ }^{25}$ It followed that the president could not remove a member of the Tribunal without stating a cause for removal.

In the meantime, Congress was engaged in a lengthy investigation and debate to devise and implement means of assuring that the hearing examiners (later renamed ALJs) who presided in hearings to adjudicate disputes between private parties and the government did so in an unbiased manner. ${ }^{26}$ Many parties who participated in those adjudications complained that ALJs behaved in ways that reflected a powerful bias in favor of the government. Many studies supported the claims of bias.

After 17 years of investigation and debate, Congress addressed the problem of bias in 1946 by enacting the Administrative Procedure Act (APA) by unanimous voice vote in both the House and Senate. ${ }^{27}$ The most important provisions of the APA are designed to assure that ALJs preside over adjudicatory hearings in an unbiased manner. They include provisions that prohibit an agency from determining the compensation of an $\mathrm{ALJ},{ }^{28}$ assigning an $\mathrm{ALJ}$ responsibilities that are inconsistent with the duties of an $\mathrm{ALJ},{ }^{29}$ and, most important, removing or otherwise punishing an ALJ. An ALJ can be removed only for cause found by the Merit Systems Protection Board (MSPB) after conducting a formal hearing. ${ }^{30}$

In its 1950 opinion in Wong Yang Sun v. McGrath, ${ }^{31}$ the Court praised Congress for investigating the serious problem of bias in hearings conducted to adjudicate disputes between private parties and the government. The Court also praised Congress for including in the APA provisions that greatly reduced the risk of bias by protecting ALJs from agency pressure to conduct 
hearings in a manner that reflected bias in favor of the agency. ${ }^{32}$ The Court compared the blatantly biased hearing that the immigration service had provided the private party in the case before the Court with the unbiased hearing that the APA assures. ${ }^{33}$ The Court held the APA applicable to immigration hearings even though Congress had not explicitly incorporated the APA safeguards of independence in the Immigration Act. ${ }^{34}$ The Court adopted a saving construction of the Immigration Act to avoid having to hold the statute unconstitutional as a violation of due process. ${ }^{35}$ Congress reacted angrily to the decision in Wong Yang Sun. It amended the Immigration Act to make it explicit that the APA safeguards of the independence of ALJs did not apply to immigration judges (IJs). Faced with a direct conflict between its views of due process and those of Congress, the Court backed down and upheld the constitutionality of the amended Immigration Act over an argument that it violates due process in its 1955 opinion in Marcello v. Bonds. ${ }^{36}$ That opinion is one of only two opinions on the removal power that were not well-reasoned and that do not fit the otherwise consistent pattern of opinions that resolve scope of removal disputes based on the functions performed by the officer whose removal is at issue.

In every other opinion, the Court distinguished clearly between officers who perform executive functions and officers who perform adjudicative functions. The Court concluded that officers who perform executive functions must be removable at will in order to assure that the president can perform the functions vested in him by Article II. The Court concluded that officers who perform adjudicative functions must be protected from at will removal in order to reduce the risk that they will conduct adjudicatory hearings in ways that reflect pro-government bias in violation of due process. The Court should overrule its holding in Marcello v. Bonds based on the powerful reasoning in its opinion in Wong Yang Sun. 
Asylum cases provide the context in which it is most important to insure that officers with adjudicative responsibilities are able to perform their duties without fear that they will be removed or otherwise punished if they do not act in ways that reflect whatever bias the president and the attorney general might have. Denial of a meritorious application for asylum is almost always followed by removal of the alien from the United States. Thus, denial of a meritorious application for asylum has devastating effects on the applicant, often including a high risk that the applicant will be killed when the applicant is forced to return to the applicant's country of origin.

The present circumstances illustrate the extreme risk of bias particularly well. Both the president and the attorney general have expressed powerful antipathy toward aliens who seek asylum and have applied extraordinary pressure on IJs to deny applications for asylum. That pressure is virtually certain to influence at least some IJs to deny applications for asylum in some cases in which their unbiased view of the merits would yield a decision granting the application. ${ }^{37}$ The attorney general has the power to evaluate the performance of IJs and to remove an IJ at will. ${ }^{38}$ It is unrealistic to believe that all IJs will have the extraordinary courage and strength of character required to act in a manner that is inconsistent with the expectations of the president and the attorney general. The Supreme Court should put an end to the blatantly unconstitutional practice of pressuring IJs to deny applications for asylum.

The only other opinion in which the Court departed from the important principles of constitutional law that underlie most of its decisions was its 1988 opinion in Morrison v. Olson. ${ }^{39}$ The Court upheld the statutory for cause limit on the power of the Attorney General to remove an independent counsel who had the power to investigate and potentially to prosecute a high-ranking officer executive officer for allegedly engaging in criminal conduct. The Court held that the limit 
on the removal power was permissible even though the Court characterized prosecution as an executive function. ${ }^{40}$

As I have explained at length elsewhere, the opinion in Morrison did no harm because, as the Court emphasized repeatedly, the independent counsel had no power to make any policy decision. ${ }^{41}$ The Court has never upheld a limit on the power to remove an officer who has the power to make policy decisions on behalf of the government. That is by far the most important function that is vested in the President in Article II.

\section{Conclusion}

I hope that the Supreme Court holds that the president must have the power to remove at will any officer who performs executive functions to enable the president to perform the functions vested in the president by Article II. I also hope that the Court holds that due process precludes the president from having the power to remove at will an officer whose sole responsibilities are to adjudicate disputes between private parties and the government. With one glaring exception, the Court's opinions are consistent with those principles when they are read with care and in the context in which they were decided. I hope that the Court eliminates the one outlier by overruling its 1955 decision in Marcello v. Bonds and holding that immigration judges cannot be removed at will.

Richard J. Pierce Jr. is Lyle T. Alverson Professor of Law at George Washington University. His 30 books and 130 articles on administrative law and government regulation have been cited in hundreds of judicial opinions, including a dozen opinions of the U.S. Supreme Court. He can be contacted at rpierce@law.gwu.edu.

\footnotetext{
1138 S.Ct. 2044 (2018).

2 The Administrative Conference of the United States (ACUS) has solicited several reports that describe in detail the functions performed by the roughly 2000 ALJs and 11,000 AJs who preside in hearings conducted by federal agencies. Those studies are available on the ACUS website.

${ }^{3}$ Brief for Respondent Supporting Petitioners, in Lucia v. SEC, U.S. Sup. Ct. No. 17-130, pp. 39-56 (Feb. 2018).

${ }^{4} 561$ U.S. 477 (2010).
} 
${ }^{5}$ PHH Corp. v. Consumer Financial Protection Board, 839 F. 3 d 1 (D.C. Cir. 2016), rev'd en banc, 881 F. $3 d 75$ (2018).

${ }^{6}$ Collins v. Mnuchin, 908 F. 3d 151 (5 $5^{\text {th }}$ Cir. 2018).

${ }^{7} 272$ U.S. 52 (1926).

8462 U.S. 919 (1983).

9478 U.S. 714 (1986).

10561 U.S. 477.

11839 F. 3d at 7.

12908 F. 3d 151.

${ }^{13} 272$ U.S. at 154-59.

${ }^{14}$ Id. at 156-57. (emphasis added).

${ }^{15} \mathrm{Id}$. at $157-58$.

${ }^{16} 561$ U.S. at 507.

${ }^{17} 295$ U.S. 602 (1935).

${ }^{18} I d$. at 629 .

${ }^{19}$ See the description of the Legislative Reorganization Act of 1946 and the Legislative Reorganization Act of 1970 in Wikipedia.

${ }^{20}$ See Ewin L. Davis, Influence of the Federal Trade Commission's Investigations on Federal Regulation of Interstate Electric and Gas Utilities, 14 Geo. Wash. L. Rev. 21 (1945).

${ }^{21} 295$ U.S. at 629.

22272 U.S. at $156-57$.

23357 U.S. 349 (1958).

${ }^{24} \mathrm{Id}$. at $353-56$.

${ }^{25} \mathrm{Id}$. at $355-56$.

${ }^{26}$ The Court described this process of debate and investigation in Wong Yang Sung v. McGrath, 339 U.S. 33, 37-41 (1950).

${ }^{27}$ The Court described the process of enacting the APA in Ramspeck v. Federal Trial Examiners Conference, 345 U.S. 128, 131-32 (1953).

285 U.S.C. $\$ 5372$.

295 U.S.C. $\$ 3105$.

305 U.S.C. $\$ 7521$.

31339 U.S. at 40.

${ }^{32} I d$. at 41 .

${ }^{33} \mathrm{Id}$. at $45-46$.

${ }^{34} \mathrm{Id}$. at 51 .

${ }^{35} \mathrm{Id}$. at $49-50$.

36349 U.S. 302 (1955).

${ }^{37}$ Catherine Y. Kim, The President's Immigration Courts, 68 Emory L. Rev. 1, 3-6 (2018).

${ }^{38}$ Kent Barnett, Logan Cornett, Malia Redick, Russell Wheeler, Non-ALJ Adjudicators in Federal Agencies: Status, Selection, Oversight and Removal, Final Report to Administrative Conference of the United States pp. 52-61 (2018). 39487 U.S. 654 (1988).

${ }^{40} I d$. at 691.

${ }^{41}$ Richard J. Pierce, Jr., Morrison v. Olson, Separation of Powers, and the Structure of Government, 1988 Sup. Ct. Rev. 1. See also Richard J. Pierce Jr., Saving the Unitary Executive Theory from Those Who Would Distort and Abuse It, 12 Penn. J. Con. L. 593 (2010) (explaining why political limits on the power to remove a special counsel are far more effective than legal limits). 